\title{
Detection of Information
}

\section{Requirements of Researchers}

Using Bibliometric Analyses to

Identify Target Journals

\section{Vadim Nikolaevich}

Gureyev, Nikolai

Alekseevich Mazov

\begin{abstract}
Bibliometric analyses were used to identify journals that are representative of the authors' research institutes. Methods to semiautomatically collect data for an institute's publications and which journals they cite are described. Citation analyses of lists of articles and their citations can help librarians to quickly identify the preferred journals in terms of the number of publications, and the most frequently cited journals. Librarians can use these data to generate a list of journals that an institute should subscribe to.
\end{abstract}

\section{BACKGROUND}

Recent developments in information technology have had a significant impact on the research activities of scientific libraries. Such tools have provided new insights into the workload and duties of librarians in research libraries. In the present study, we performed bibliometric analyses to determine the information needs of researchers, and to determine whether they are satisfied with the journal subscriptions available at their institutes. Such analyses are important because of limited funding for subscriptions, increases in the cost of electronic resources, and the publication of new journals, especially open-access journals.

Bibliometric analyses are more accessible and less labor-intensive when using specially designed web services and software. Several databases of citation data are accessible online. The leading publishers of these databases, including Thomson Reuters and Elsevier, promote their products such as the Web of Science (WoS) and Scopus with travelling and online seminars to increase the number of skilled users. Of note, the number of articles devoted to bibliometric analysis has increased about 4-fold since 2000 (see Figure 1).

Vadim Nikolaevich Gureyev (gureyev@vector.nsc.ru) is Leading Bibliographer, Information Analysis Department, State Research Center of Virology and Biotechnology Vector, Novosibirsk, Russia. Nikolai Alekseevich Mazov (mazovNA@ipgg.sbras.ru) is Head of Information and Library Center, Trofimuk Institute of Petroleum Geology and Geophysics SB RAS, Novosibirsk, Russia. 


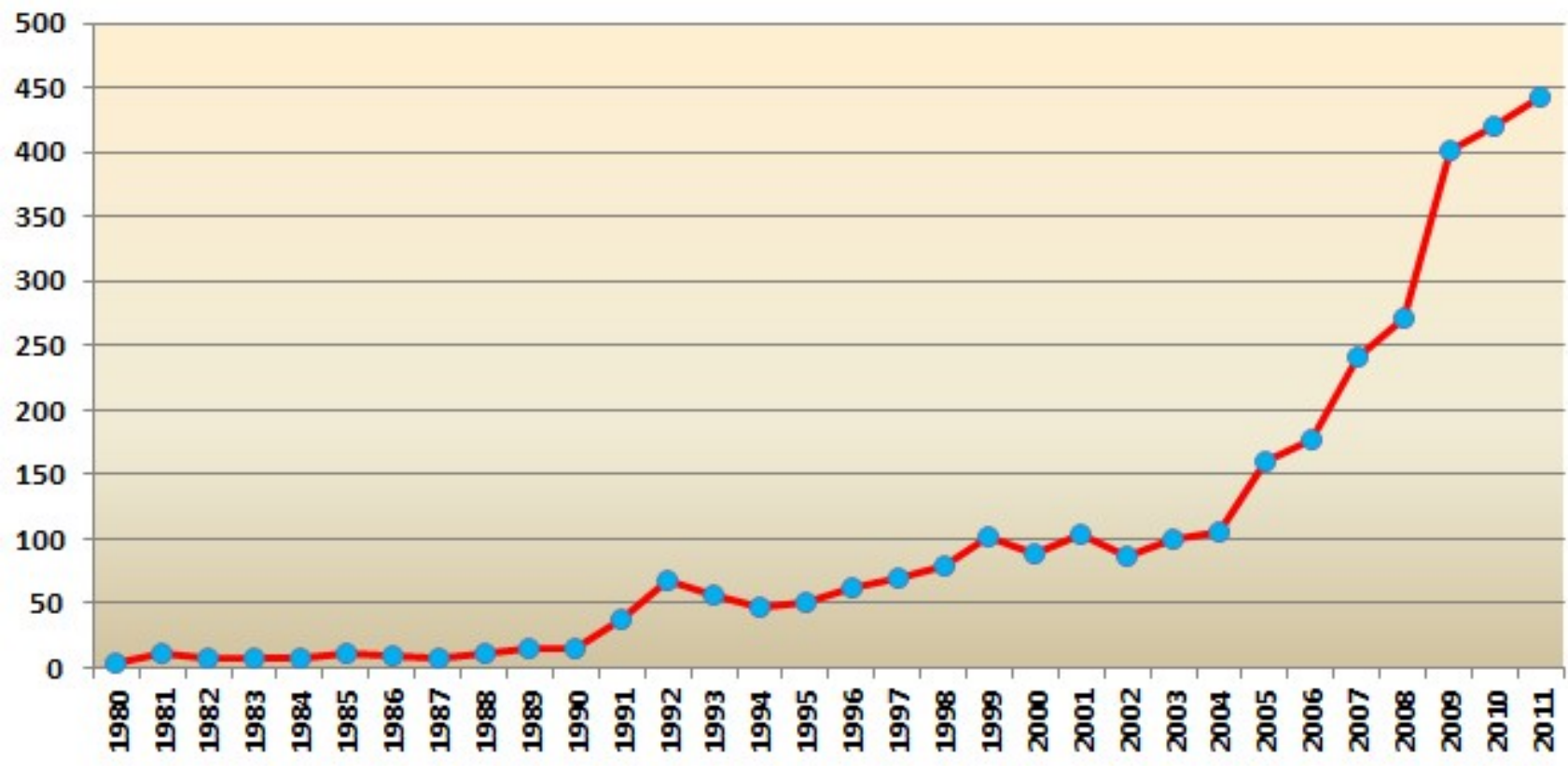

Figure 1. Growth of publications devoted to informetric analysis. Data were generated from the WoS using the following request: «Topic=((bibliometric* or informetric* or webometic* or scientometric*) and (stud* or analys*))».

Bibliometric analysis appears to be the most objective method for use by librarians. It is important to note that bibliometric analysis shows high objectivity, even when compared with peer review. ${ }^{1}$

Citation analysis can be used to select target journals because it accurately reflects the needs of researchers and can reveal current scientific trends. It also allows librarians to evaluate the effectiveness of each journal, the significance of each journal to the institute, and the minimum archival depth. ${ }^{2}$ Citation analysis is particularly useful when generating a list of journals for subscription and to determine whether to subscribe to specific journals. ${ }^{3}$

In the present study, we performed citation analyses of scientific papers that were published by researchers at SRC VB "Vector" (biology and medicine) and IPGG SB RAS (geosciences). We analyzed groups of journals that published articles from these two institutes and compared the characteristics of the cited and citing journals.

Many journals publish articles covering the fields associated with the two institutes (biology and medicine, and geosciences), and journals in these fields tend to have the highest impact factors of all fields. Therefore, the methods applied in this study and the results may be generalized to other research libraries. 


\section{STUDY DESIGN}

Sources. We analyzed articles published in journals or books by researchers at SRC VB "Vector" and IPGG, together with the references cited in these articles. We limited the articles to those published in 2006-2010 (IPGG) or 2007-2011 (SRC VB “Vector"). We did not analyze monographs, theses, or conference proceedings (including those that were published in journals), because our aim was to optimize the list of subscribed journals. To collect comprehensive data regarding these publications, we used four overlapping sources. (1) The Russian Science Citation Index (SCI) was used to retrieve articles based on the profile of each researcher. The "Bound and Unbound Publications in One List" option was switched off. (2) Thomson Reuters SCI Expanded was used to examine the profile of each researcher. The "Conference Proceedings Citation Index" option was switched off. (3) Scopus was used to retrieve the publications for each researcher. (4) Each head of department provided us with the articles published by each member of the research group within the last 5 years.

Along with publications in which the affiliation was clearly stated, we also analyzed articles where the authors' affiliation was not stated, the authors reported a superior organization such as a governmental ministry, and the authors from either institute attributed the work to another affiliation (if they worked at two or more organizations). The translated and original versions of the same article were treated as a single article, and the English version was used in our analyses. For journals that published the original Russian article and an English translation, we analyzed the latter.

Citations. Citations from the published articles were analyzed to identify the most frequently cited journals. We ignored references that lacked sufficient information or references included in footnotes. Cited monographs, theses, and conference proceedings (including those that were published in journals) were also ignored. For citations published in Russian with an English translation, we analyzed the translated version, even if the authors originally cited the Russian version. We preferred to include the translated versions because they are included in WoS database and we can treat them automatically. For example, the WoS indexes articles from Russian Geology and Geophysics (print ISSN 1068-7971) but not the Russian-language version Geologiya $i$ Geofizika (print ISSN 0016-7886). Journals that had been renamed were treated as one journal, and the current/most recent name was used in the analysis. However, journals that had split into multiple titles were analyzed separately, and the journal's name at the time the cited article was published was used in the analysis.

For this study, we first retrieved the journal name and the year the cited article was published. We then expanded on this information by recording the journal publisher, journal accessibility (i.e. subscription method, paper or electronic), open/pay-per-view access, embargo status, and journal length. We ignored the accessibility of individual articles that had been deposited in the author's personal website or in an institutional repository. 


\section{RESULTS AND DISCUSSION}

Table 1 summarizes the publication activities for both institutes.

A.

\begin{tabular}{lllllll}
\hline Year & $\begin{array}{l}\text { Number } \\
\text { of articles }\end{array}$ & $\begin{array}{l}\text { Included in } \\
\text { Russian } \\
\text { SCI* }(\%)\end{array}$ & $\begin{array}{l}\text { Included in } \\
\text { WoS (\%) }\end{array}$ & $\begin{array}{l}\text { Included } \\
\text { in Scopus* } \\
(\%)\end{array}$ & $\begin{array}{l}\text { Nowhere } \\
\text { indexed (\%) }\end{array}$ & $\begin{array}{l}\text { Number of } \\
\text { journals** }\end{array}$ \\
\hline 2007 & 118 & 94.9 & 28.8 & 54.2 & 5 & 66 \\
2008 & 84 & 96.4 & 41.6 & 51.1 & 3.5 & 57 \\
2009 & 82 & 97.5 & 39 & 52.4 & 2.4 & 58 \\
2010 & 100 & 94.0 & 41 & 61 & 6 & 60 \\
2011 & 105 & 91.4 & 25.7 & 55.2 & 8.5 & 50 \\
\hline
\end{tabular}

B.

\begin{tabular}{lllllll}
\hline Year & $\begin{array}{l}\text { Number } \\
\text { of articles }\end{array}$ & $\begin{array}{l}\text { Included in } \\
\text { Russian } \\
\text { SCI* }(\%)\end{array}$ & $\begin{array}{l}\text { Included in } \\
\text { WoS }(\%)\end{array}$ & $\begin{array}{l}\text { Included } \\
\text { in Scopus* } \\
(\%)\end{array}$ & $\begin{array}{l}\text { Nowhere } \\
\text { indexed (\%) }\end{array}$ & $\begin{array}{l}\text { Number of } \\
\text { journals** }\end{array}$ \\
\hline 2007 & 188 & 79.8 & 43.1 & 43.1 & 21 & 82 \\
2008 & 218 & 96.8 & 39.4 & 41.7 & 3 & 88 \\
2009 & 259 & 93.0 & 39.0 & 37.8 & 7 & 87 \\
2010 & 250 & 84.4 & 31.2 & 29.6 & 5 & 102 \\
2011 & 267 & 70.4 & 30.4 & 30.0 & 29 & 97
\end{tabular}

*The Russian SCI and Scopus indexed some articles twice, particularly those published in Russian with an English translation. Therefore, some articles have different timelines and citations. These duplications were analyzed as one article.

**Number of journals in this field, excluding translated journals.

Table 1. Publication activity and articles presence in the main bibliographic databases in the fields of biomedicine $(A ; 2007-2011)$ and geoscience $(B ; 2007-2011)$.

Table 1 shows that the two institutes have a stable publication history relative to other Russian scientific institutes in terms of publication activity, in publishing approximately 150 articles per year. Therefore, our results can be generalized to other institutes in these fields.

Collecting this information may seem to be a daunting task, especially for librarians who have not conducted such analyses before. We used three databases and contacted the heads of department 
directly. However, our data indicate that it is sufficient to use the free-of-charge Russian SCI, an extensive index of Russian scientific articles that includes almost all of the articles published by Russian researchers in Russian and international journals. Nevertheless, it is essential to review the profile of each author. When searching for articles by affiliation, the number of articles retrieved ranged from $28 \%$ to $51 \%$, but the number of publications retrieved tended to decrease over time. This phenomenon may be caused by a deficient system used to identify affiliations because of differences in the spelling of the affiliation name (in our case, more than 70 variants have been used), attribution of the research to a superior organization, and two or more affiliations may have the same name. ${ }^{4}$ Furthermore, recent studies ${ }^{1,5}$ confirmed that information about authors should be collated by their affiliations, rather than by performing searches in bibliographic databases.

It seems paradoxical that the WoS and Scopus databases index Russian articles quicker than the Russian SCI. By subscribing to the same print and electronic journals, we noted that print editions are published before electronic ones. Nevertheless, this seems reasonable based on this 2-year retrospective analysis. Therefore, routine analysis of Russian articles can be partly automated by efficient searches of the Russian SCI.

Table 2 presents the citation details.

\begin{tabular}{llll}
\hline $\begin{array}{l}\text { Citing } \\
\text { year }\end{array}$ & $\begin{array}{l}\text { Number } \\
\text { of } \\
\text { references }\end{array}$ & $\begin{array}{l}\text { Number of } \\
\text { cited journals }\end{array}$ & $\begin{array}{l}\text { Average number of } \\
\text { references in article }\end{array}$ \\
\hline 2007 & 1830 & 492 & 15.5 \\
2008 & 1354 & 472 & 16.1 \\
2009 & 1536 & 558 & 18.7 \\
2010 & 1591 & 471 & 15.9 \\
2011 & 1613 & 484 & 15.4 \\
\hline
\end{tabular}

Table 2. Number of cited articles, cited journals, and mean number of references in article in the biomedical field

References from articles not indexed in WoS were manually extracted, which takes time and effort. References from articles indexed in the WoS, including Russian articles translated into English, were analyzed semiautomatically. For this purpose, we used EndNote software developed by Thomson Reuters. EndNote web is a free alternative that could also be used for this purpose. The references cited in each article were exported into EndNote. Next, the references were arranged according to the chosen parameters to simplify our analyses. Of note, about $35 \%$ of the Russian articles indexed in WoS accounted for $80 \%$ of all the references cited in the articles. Two possibly reasons for this are (1) the greater number of articles published in translated and international 
journals, and (2) Russian researchers are adopting the Western citing culture. ${ }^{6}$ This finding suggests that it is possible to avoid labor-intensive routine work and to use automated services developed by Thomson Reuters to collate and analyze up to $80 \%$ of all references.

The authors of articles in the geosciences field cited 1000 journals, including 750 in Western journals and 250 in Russian journals. In terms of biomedical articles, the index included 1339 articles, of which 1168 were in Western journals and 171 in Russian journals. We analyzed about 8000 references cited by authors from each institute over 5 years. The references were divided into three equal groups. The most frequently cited Russian journals and book series are listed in Table 3.

\begin{tabular}{|c|c|c|c|c|c|}
\hline \multicolumn{3}{|l|}{ Biological and medical sciences } & \multicolumn{3}{|l|}{ Geosciences } \\
\hline Journals/Book series & $\begin{array}{l}\text { Percent of } \\
\text { references }\end{array}$ & $\begin{array}{l}\text { Total } \\
(\%)\end{array}$ & Journals/Book series & $\begin{array}{l}\text { Percent of } \\
\text { references }\end{array}$ & $\begin{array}{l}\text { Total } \\
(\%)\end{array}$ \\
\hline Problems of Virology & 16.94 & 16.94 & Russian Geology and Geophysics & 34.99 & 34.99 \\
\hline Molecular biology & 6.44 & 23.38 & Doklady Earth Sciences & 18.18 & 53.17 \\
\hline Biotechnology in Russia & 6.07 & 29.45 & Geochemistry International & 6.49 & 59.66 \\
\hline Doklady Biological Sciences & 5.09 & 34.54 & Petrology & 2.72 & 62.38 \\
\hline Atmospheric and Oceanic Optics & 4.42 & 38.96 & Geotectonics & 2.55 & 64.93 \\
\hline $\begin{array}{l}\text { Annals of the Russian Academy } \\
\text { of Medical Sciences } \\
\text { Journal of Microbiology, }\end{array}$ & 4.04 & 43 & Geology of Ore Deposits & 2.23 & 67.16 \\
\hline $\begin{array}{l}\text { Epidemiology and } \\
\text { Immunobiology }\end{array}$ & 3.82 & 46.82 & National geology & 1.98 & 69.14 \\
\hline $\begin{array}{l}\text { Molecular Genetics } \\
\text { Microbiology And Virology }\end{array}$ & 2.92 & 49.74 & $\begin{array}{l}\text { Stratigraphy and Geological } \\
\text { Correlation }\end{array}$ & 1.96 & 71.1 \\
\hline $\begin{array}{l}\text { Bulletin of Experimental } \\
\text { Biology and Medicine }\end{array}$ & 2.77 & 52.51 & $\begin{array}{l}\text { Izvestiya. Physics of the Solid } \\
\text { Earth }\end{array}$ & 1.55 & 72.65 \\
\hline $\begin{array}{l}\text { Russian Journal of Bioorganic } \\
\text { Chemistry }\end{array}$ & 2.69 & 55.2 & $\begin{array}{l}\text { Proceedings of All-union } \\
\text { Mineralogic Society }\end{array}$ & 1.45 & 74.1 \\
\hline Problems of Tuberculosis & 2.62 & 57.82 & $\begin{array}{l}\text { Bulletin of the Russian Academy } \\
\text { of Sciences: Geology }\end{array}$ & 1.42 & 75.52 \\
\hline Biochemistry (Moscow) & 1.79 & 59.61 & Lithology and Mineral Resources & 1.42 & 76.94 \\
\hline $\begin{array}{l}\text { Pharmaceutical Chemistry } \\
\text { Journal }\end{array}$ & 1.72 & 61.33 & Oil and gas geology & 1.26 & 78.2 \\
\hline Infectious Diseases & 1.57 & 62.9 & Russian Journal of Pacific Geology & 0.82 & 79.02 \\
\hline $\begin{array}{l}\text { Bulletin Siberian Branch of } \\
\text { Russian Academy of Medical } \\
\text { Sciences }\end{array}$ & 1.2 & 64.1 & $\begin{array}{l}\text { Chemistry for Sustainable } \\
\text { Development }\end{array}$ & 0.69 & 79.71 \\
\hline Russian Journal of Genetics & 1.12 & 65.22 & Physics of the Solid State & 0.68 & 80.39 \\
\hline
\end{tabular}

Table 3. Characteristics of the 16 most frequently cited Russian journals and journals in the second group listed in order of number of citations. The journals in the colored region include one-third of all citations. The translated titles of each journal and the official translated titles of journals without translated variants are given. 
Table 3 shows that two-thirds of all citations were published in only $9 \%(16 / 171)$ of the cited Russian biomedical journals. This statistic is even more pronounced in the field of geosciences, as $6 \%$ (16/250) of Russian journals published $80 \%$ of the cited articles. Comparing the data between the two institutes, it is notable that the results are consistent. The only difference evident to us is that the geoscience researchers tended to cite more Russian journals, whereas biomedical researchers preferred to cite international literature. The greater concentration of citations to select journals in the geosciences field can be explained by the smaller number of citations. In the biomedical field, we observed a high trend towards abundant citations resulting in a wider distribution of citations in each article; the journals with the highest impact factors in biology and medicine confirmed our observation. Figures 2 and 3 show the correlations between citations and publication activity in Russian journals.

Figure 2. Correlation between publication activity (red) and citations (blue) in the biomedical field (in \%) for the data shown in Table 3. Timescale: 2007-2011.

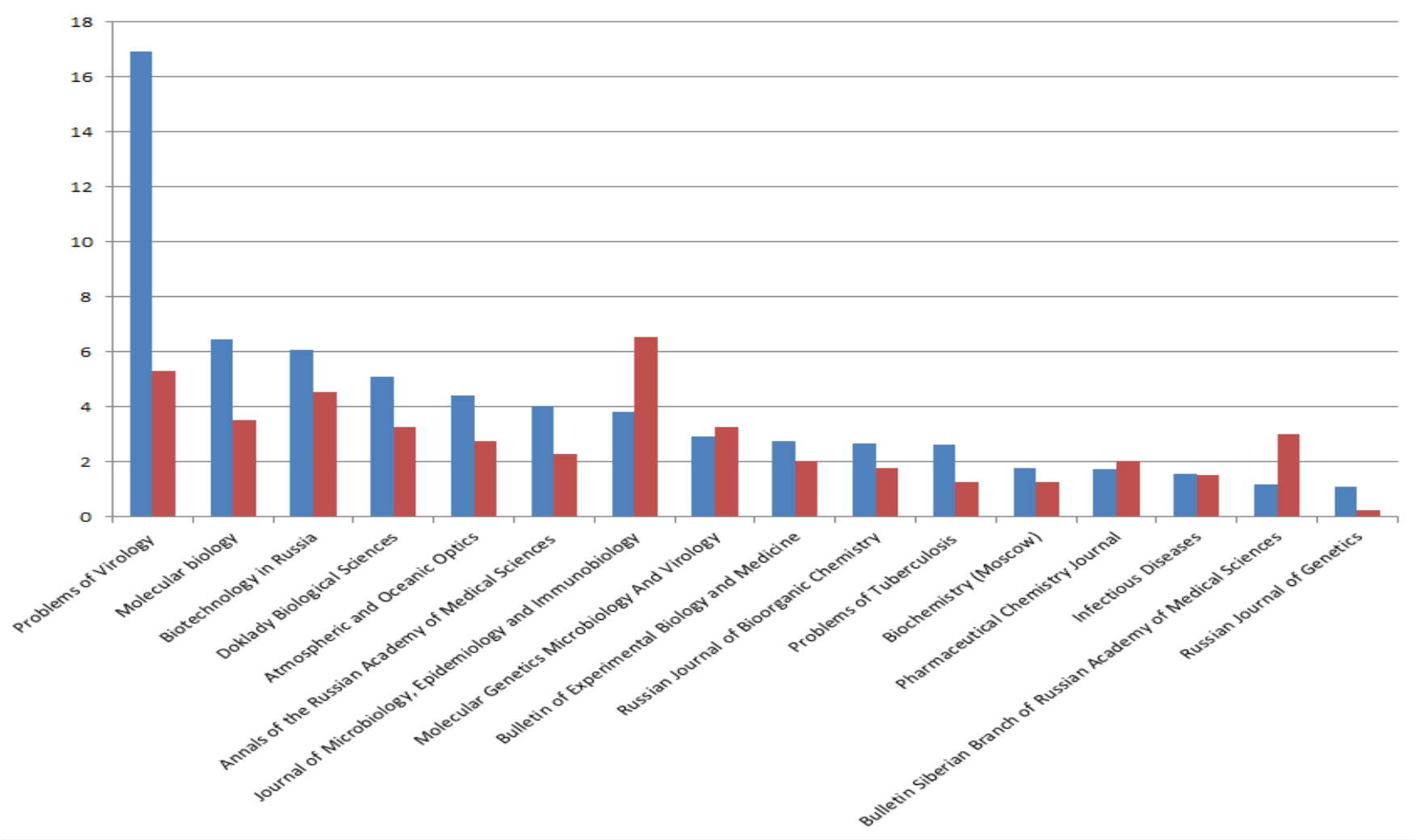

Figure 3. Correlation between publication activity (red) and citations (blue) in the geosciences field (in \%) for the data shown in Table 3. Timescale: 2006-2010. 


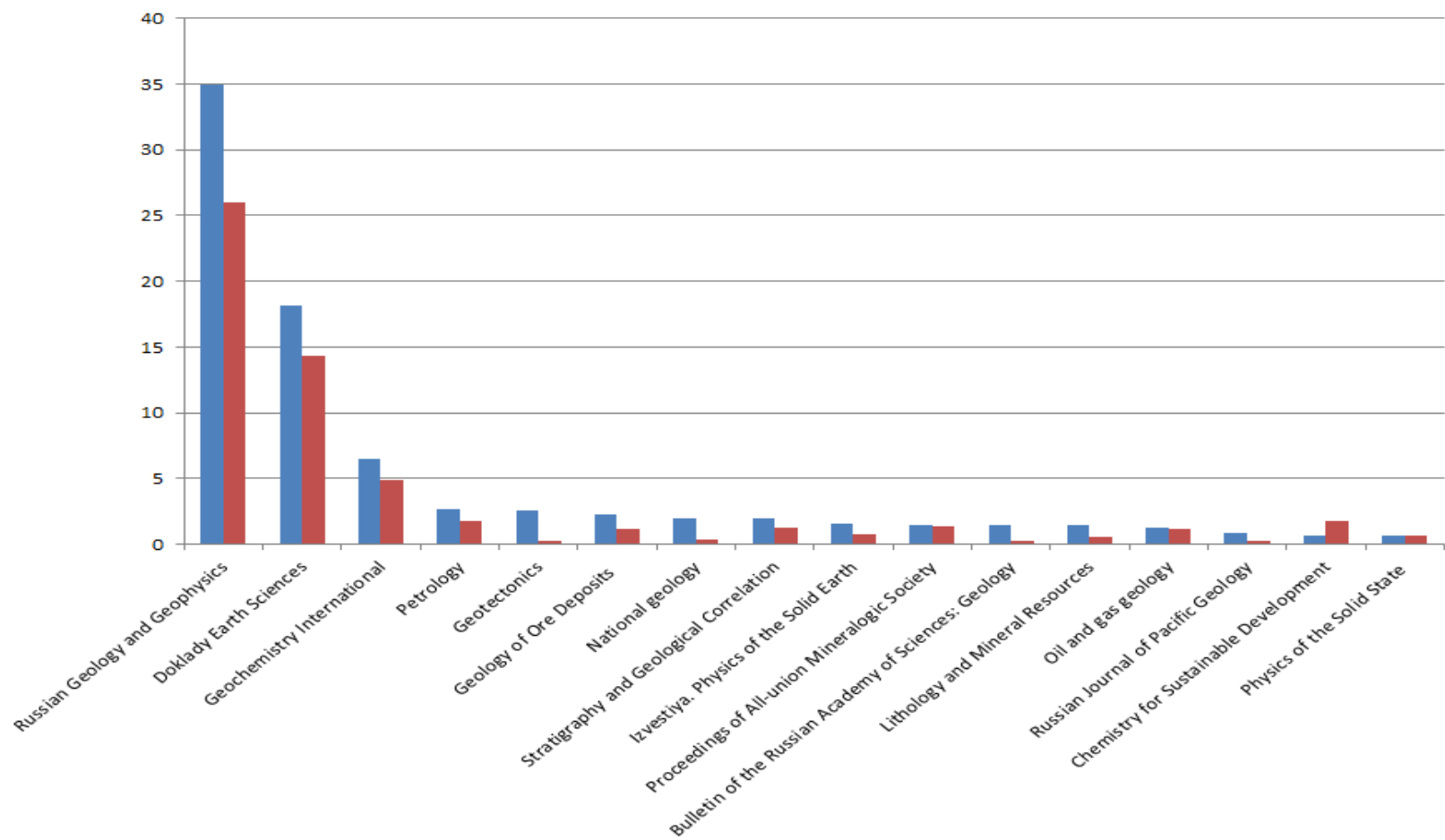

The citing and cited journals are often the same journals, and publication activity is highly correlated with citation activity. This is more apparent in the geosciences field, where Russian Geology and Geophysics is the most frequently cited journal, as it published about two-thirds of all cited articles. This is unsurprising because it is published by our institute and is the main multidisciplinary Russian journal in the field of geosciences. The most frequently cited international journals are listed in Table 4.

\begin{tabular}{lrrlrr}
\hline Biological and medical sciences & & & Geosciences & \\
\hline Journals/Book series & $\begin{array}{l}\text { Percent of } \\
\text { references }\end{array}$ & $\begin{array}{l}\text { Total } \\
(\%)\end{array}$ & Journals/Book series & $\begin{array}{l}\text { Percent of } \\
\text { references }\end{array}$ & $\begin{array}{l}\text { Total } \\
(\%)\end{array}$ \\
\hline $\begin{array}{l}\text { Journal of Virology } \\
\text { Proceedings of the National }\end{array}$ & 6.03 & 6.03 & Earth Planetary Science Letters & 6.46 & 6.46 \\
$\begin{array}{l}\text { Academy of Sciences of the } \\
\text { United States of America }\end{array}$ & 3.36 & 9.39 & Geochimica et Cosmochimica Acta & 6.28 & 12.74 \\
Virology & & & & & \\
Vaccine & 3.15 & 12.54 & Contributions to Mineralogy and & 5.67 & 18.41 \\
Journal of Biological Chemistry & 2.77 & 15.31 & Journal of Geophysical Research & 4.9 & 23.31 \\
Journal of General Virology & 2.4 & 17.71 & Nature & 3.67 & 26.98 \\
Nature & 2.4 & 20.11 & American Mineralogist & 3.53 & 30.51 \\
Science & 2.04 & 22.15 & Journal of Petrology & 3.22 & 33.73 \\
Journal of Clinical Microbiology & 1.94 & 24.09 & Lithos & 2.58 & 36.31 \\
Emerging Infectious Diseases & 1.94 & 26.03 & Chemical Geology & 2.29 & 38.6 \\
Nucleic Acids Research & 1.89 & 27.92 & Geology & 2.01 & 40.61 \\
Journal of Infectious Diseases & 1.59 & 29.51 & Tectonophysics & 1.94 & 42.55 \\
& 1.38 & 30.89 & Economic Geology & 1.93 & 44.48
\end{tabular}




$\begin{array}{lrrlrl}\text { Journal of Molecular Biology } & 1.35 & 32.24 & \text { Science } & 1.87 & 46.35 \\ \text { Journal of Immunology } & 1.24 & 33.48 & \text { Journal of Crystal Growth } & 1.56 & 47.91 \\ \text { Journal of Medical Virology } & 1.19 & 34.67 & \text { Canadian Mineralogist } & 1.48 & 49.39 \\ \text { Virus Research } & 0.86 & 35.53 & \text { Russian Geology and Geophysics } & 1.35 & 50.74 \\ \text { New England Journal of } & 0.86 & 36.39 & \text { European Journal of Mineralogy } & 1.32 & 52.06 \\ \text { Medicine } & 0.83 & 37.22 & \text { Geophysics } & 1.02 & 53.08 \\ \text { Archives of Virology } & 0.75 & 37.97 & \text { Geophysical Research Letters } & 1.02 & 54.1 \\ \text { Antiviral Research } & 0.73 & 38.7 & \text { Journal of Metamorphic Geology } & 0.98 & 55.08 \\ \text { Lancet } & 0.65 & 39.35 & \text { Journal of Geology } & 0.93 & 56.01 \\ \text { Cell } & 0.6 & 39.95 & \text { International Geology Review } & 0.91 & 56.92 \\ \text { Applied and Environmental } & 0.59 & 40.54 & \text { Physical Review. Ser. B } & 0.9 & 57.82 \\ \text { Microbiology } & 0.59 & 41.13 & \text { Precambrian Research } & 0.9 & 58.72 \\ \text { Biochemistry } & 0.56 & 41.69 & \text { Mineralogical Magazine } & 0.88 & 59.6 \\ \text { Journal of Experimental } & & & & \end{array}$

Table 4. Characteristics of the 25 most frequently cited international journals and journals within the second group listed in terms of number of citations. The colored area includes one-third of all citations.

The distribution of citations to international journals was similar to that observed for Russian journals, with a greater citation density in journals in the geosciences field. Notably, two-thirds of all citations were to articles published in just 25 journals. In terms of biomedical journals, twothirds of all citations were to articles published in 100 journals. Only 1.3\% (15/1 168) of the cited journals contained one-third of the cited articles in the biomedical field. The corresponding value for journals in the geosciences field was $0.9 \%$ (7/750). The correlations between citation activity and publication activity are shown in Figures 4 and 5. 


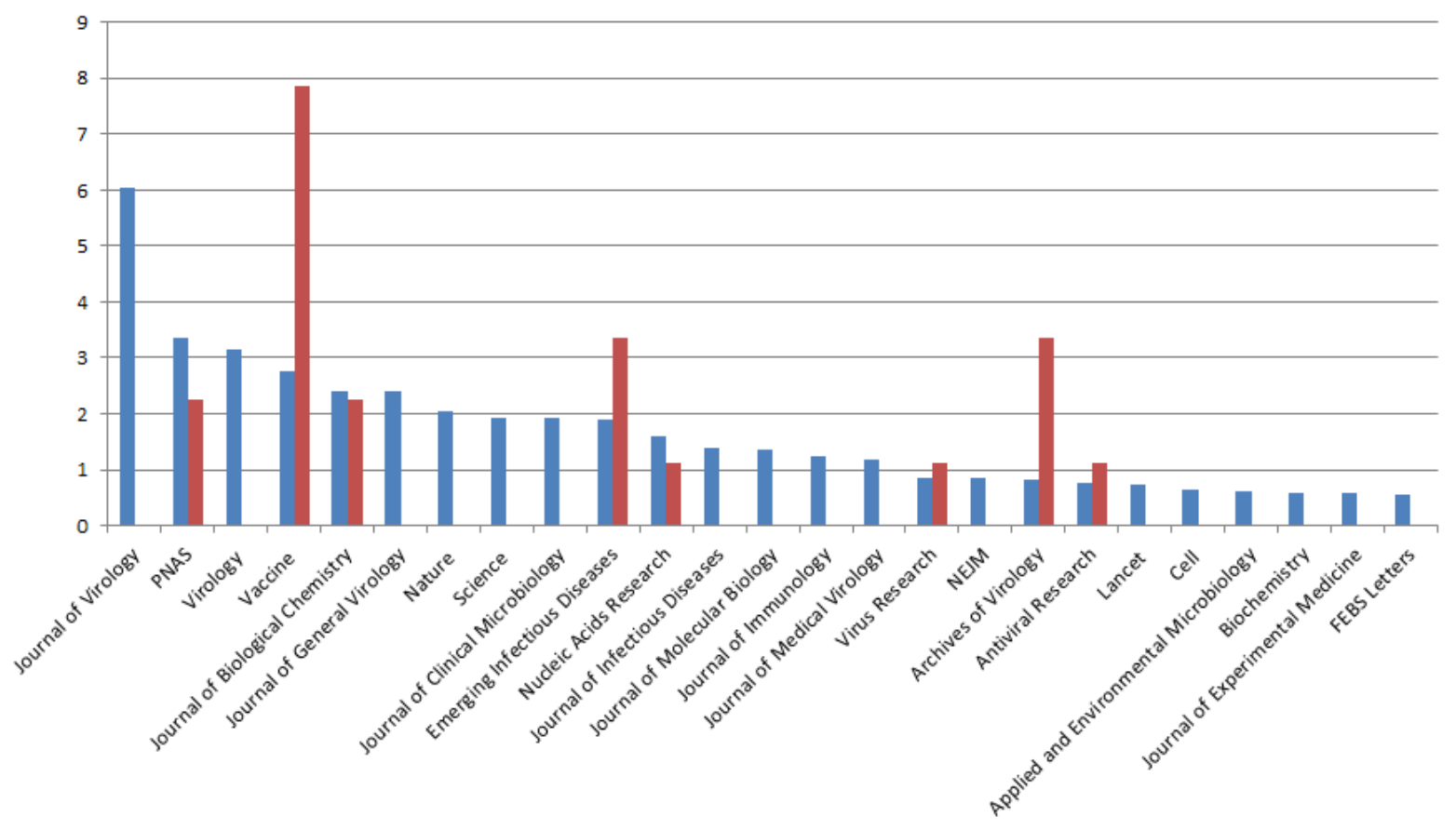

Fig. 4. Correlation between publication activity (red) and citations (blue) for biomedical journals (in \%) for the data shown in Table 4. Timescale: 2007-2011.

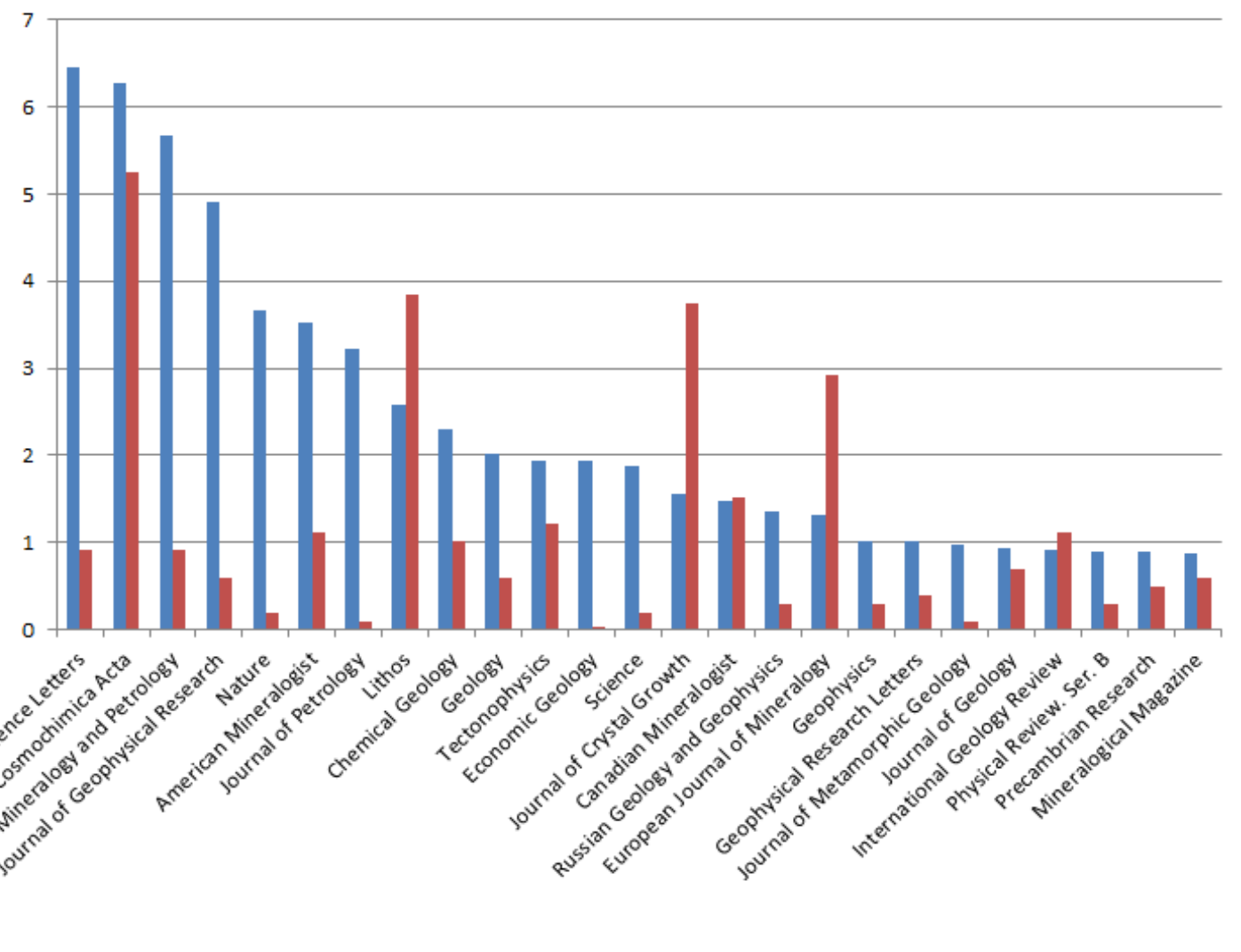

Fig. 5. Correlation between publication activity (red) and citations (blue) for journals in the geosciences field (in \%) for the data shown in Table 4. Timescale: 2006-2010 
As illustrated in Figures 4 and 5, the distribution of citations to international journals was broader than for Russian journals, where there are only 1-4 frequently cited journals. This is probably due to the smaller number of Russian journals than international journals. Figures 4 and 5 also revealed a difference between the two disciplines, as geoscience researchers published their articles in top cited international journals, whereas biomedical researchers rarely published their research in highly cited journals. This may be due to the greater number of biomedical journals or the lower rate of publication, because relatively few articles were published in the major multidisciplinary journals, such as Nature or Science, or in specialized journals, such as the Journal of Virology.

\section{CONCLUSION}

Citation analysis enabled rapid identification of the most frequently cited journals that are essential to academic researchers. In the biomedical field, we found that 16 Russian and 100 international journals published two-thirds of all cited articles in the last 5 years. In the field of geosciences, we identified 4 Russian and 25 international journals that were essential to researchers in this field. Interestingly, there were four times as many Russian and international journals in the biomedical field than in the geosciences field.

The journals that published the researchers' articles were partially correlated with the cited journals in the geosciences field, but this correlation was less obvious for biomedical journals.

It is important to note that all aspects of this study were performed by librarians who used tools that were available in both institutes. We did not require any additional facilities or the assistance of any researchers. We believe our method is one of the most objective and accessible approach for scientific libraries to select target journals. We used our results to optimize subscribed periodical items.

In addition to journal acquisition, our methods and results may be applied to other tasks that may be performed by research libraries. For example, it is possible to study the citing and cited halflives of journals, and compare the results with those reported in the Journal Citation Reports. This allows researchers in specific institutes to determine whether they are citing cutting edge or obsolete literature in their studies. The results can also be used to determine whether the subjects of the cited articles are relevant to the institute's field of research. Finally, the results can be used to compare the list of the most frequently cited international journals within a particular field with the list of journals that are most frequently cited by a research institute.

\section{PERSPECTIVES}

In this study, we revealed some differences in the correlation between citing and cited journals in two distinct fields, namely geosciences and biomedical science. Notably, this correlation was greater for journals in the geosciences field. To determine the factors underlying this phenomenon, it will be interesting to extend our study to a greater number of disciplines. It will also be interesting to compare data for cited journals with their usage statistics. 


\section{REFERENCES}

1. A.F.J. van Raan. "The use of bibliometric analysis in research performance assessment and monitoring of interdisciplinary scientific developments." Technikfolgenabschätzung - Theorie und Praxis, Vol. 1 no.12 (2003): 20-29.

2. N.A. Slashcheva, Yu.V. Mokhnacheva and T.N. Kharybina. (2008)/ "Study of information requirement of scientists from Pushchino Scientific Center RAS in Central Center library." http://dspace.nbuv.gov.ua:8080/dspace/bitstream/handle/123456789/31392/20Slascheva.pdf?sequence=1 (accessed January 21, 2013).

3. Nikolay A. Mazov. "Estimation of a flow of scientific publications in research institute on the basis bibliometric citation analysis". Information technologies in social researches, no.16 (2011): 25-30.

4. Leo Egghe and Ronald Rousseau. "Citation analysis", In Introduction to informetrics: Quantitative methods in library, documentation and information science. Amsterdam: Elsevier science publishers. (1990): 217-218.

5. "Bibliometrics Publication Analysis as a Tool for Science Mapping and Research Assessment." (2008), http://ki.se/content/1/c6/01/79/31/introduction to bibliometrics v1.3.pdf (accessed January 21, 2013).

6. A.E. Warshawsky and V.A. Markusova. (2009). "Estimation of efficiency of Russian scientists should be corrected." http://strf.ru/organization.aspx?CatalogId=221\&d no=17296 (accessed January 21, 2013). 